\title{
Innovation, low energy buildings and intermediaries in Europe: systematic case study review
}

\author{
Paula Kivimaa $(\mathbb{D})$ Mari Martiskainen
}

Received: 17 May 2016 / Accepted: 10 July 2017 / Published online: 24 July 2017

(C) The Author(s) 2017. This article is an open access publication

\begin{abstract}
As buildings throughout their life cycle account for circa $40 \%$ of total energy use in Europe, reducing energy use of the building stock is a key task. This task is, however, complicated by a range of factors, including slow renewal and renovation rates of buildings, multiple non-coordinated actors, conservative building practices and limited competence to innovate. Drawing from academic literature published during 2005-2015, this article carries out a systematic review of case studies on low energy innovations in the European residential building sector, analysing their drivers. Specific attention is paid to intermediary actors in facilitating innovation processes and creating new opportunities. The study finds that qualitative case study literature on low energy building innovation has been limited, particularly regarding the existing building stock. Environmental concerns, EU and national and local policies have been the key drivers; financial, knowledge and social sustainability and equity drivers have been of modest importance; while design, health and comfort and market drivers have played a minor role. Intermediary organisations and individuals have been important through five processes: (1) facilitating individual building projects, (2) creating niche markets, (3)
\end{abstract}

\footnotetext{
P. Kivimaa $(\bowtie)$

SPRU, University of Sussex, Jubilee Building, Falmer,

Brighton BN1 9SL, UK

e-mail: p.kivimaa@sussex.ac.uk

P. Kivimaa · M. Martiskainen

SPRU, University of Sussex, Mechelininkatu 34a, P.O. Box 140, 00251 Helsinki, Finland
}

implementing new practices in social housing stock, (4) supporting new business model creation and (5) facilitating building use post-construction. The intermediaries have included both public and private actors, while local authority agents have acted as intermediaries in several cases.

Keywords Innovation · Mediators · Intermediaries · Energy efficiency $\cdot$ Low energy buildings

\section{Introduction}

System level innovation has been called for to achieve reduction in the energy use by buildings (e.g. Mlecnik 2013a) that amounts to circa $40 \%$ of the total energy use and over $30 \%$ of greenhouse gas emissions in Europe (Meeus et al. 2012). While much attention has been paid to innovation and diffusion in renewable energy innovations, such as heat pumps (Caird et al. 2012; Hyysalo et al. 2013), more systemic innovation in the energy efficiency of buildings has received much less focus in innovation studies. What we call "low energy" building innovations deserve attention, because the renewal rate of buildings is extremely slow (e.g. Meeus et al. 2012). Changes to the building stock are relatively rare and, thus, at those times when buildings are addressed via renovation or new build, systemic innovation is important to generate maximum improvement. We argue that this implies focus not only on what happens in construction projects but also on what kind of business models incorporating, for example, new designs of pre- 
fabricated "nearly zero-energy dwellings" (cf. Mlecnik 2012) or "zero carbon homes" (Berry et al. 2013), are being created to enable the diffusion of low energy housing innovations.

In the context of achieving significant low energy transition in the building and housing sector, both the diffusion of existing technologies (cf. Barnes 2016) and the emergence and diffusion of novel systemic and architectural innovations for residential buildings (e.g. Mlecnik 2013a) are needed. The term "innovation" has frequently been used to mean the introduction of a new product, process, method or system into the economy (Freeman 1987), i.e. an invention is taken into use. Systemic innovation refers to the integration of several independent innovations (e.g. technical products, applications, services) to work together to perform new functions or to improve performance as a whole (Cainarca et al. 1989). Architectural innovation is defined as novel combinations of existing technologies and components in a novel way (Henderson and Clark 2004). These differ from modular innovation that is typically one specific technology (Henderson and Clark 2004), such as better windows in or solar panels on top of a building. Our focus here is particularly on architectural and systemic innovation in low energy buildings. To get insights into the nature of innovation that happens in connection to the energy efficiency of buildings, in particular what drives it, and how these have been reported in peer-reviewed academic literature, we carry out a review of scholarly case studies published in peerreviewed journals.

Innovation and diffusion in the building sector are difficult due to a variety of factors making the current regime very stable. In many countries, the building sector consists of a multitude of actors, such as contractors, designers, installers of materials and technology and municipal governments, who have not structurally coordinated their activities (e.g. Tambach et al. 2010; Killip 2013) and who do not have competence or resources to innovate independently (Mlecnik 2013a). The sector is often conservative, especially regarding renovation processes, building materials and work habits (e.g. Davies and Osmani 2011; Killip 2013), and distant from science-based research (Arora et al. 2014). Devising solutions to the high energy problem is also difficult due to heterogeneous building ownership and housing arrangements (e.g. Meeus et al. 2012). Rochracher (2001, p.138) argued already 15 years ago that "sustainable buildings require (to a varying extent) high-tech components, which are supplied by specialized companies (building control technologies, windows, heating systems, use of solar energy, transparent insulation materials, heat recovery systems, etc.)".

Drawing from the above, it is clear that achieving systemic - or even architectural-innovation in the building sector is challenging both in terms of creating networks and gaining support for the emergence of such innovations as well as disrupting the high energy institutions and practices of the existing building regime. Many scholars have explored the topic in different local and national contexts (e.g. Mlecnik 2010, 2013a; Fawcett 2014; Pässilä et al. 2015; Nykamp 2016), while overarching analyses of case studies, in particular, of the peer-reviewed literature are rare. Therefore, we present a systematic review of peer-reviewed academic literature, focusing on case studies, to explore the status and drivers for low energy building innovation in Europe.

Taking a long-term transitions perspective, we briefly connect to two core theories in the field of sustainability transitions: the multi-level perspective (e.g. Geels 2002) and strategic niche management (e.g. Smith and Raven 2012). These theories are used for building an analytical framework for the systemic review. Among other drivers, particular attention is paid to whether specific intermediary agents (Hargreaves et al. 2013; Kivimaa 2014) have been present in facilitating the innovation processes and in what ways. Innovation intermediaries, i.e. "actors who create spaces and opportunities for appropriation and generation of emerging technical or cultural products by others who might be described as developers and users" (Stewart and Hyysalo 2008, p. 296), are of interest, because they have been envisaged as keystone players in the ecosystems where innovations develop (Clarysse et al. 2014) and, thus, they could be crucial also in building sector innovation.

The article addresses the following research questions. Based on a systematic review of academic case studies:

1. What drivers have been important for systemic and architectural innovation in low energy buildings in Europe?

2. What actors act as intermediaries and through what processes do they intermediate systemic and architectural innovation in low energy buildings?

The "Sustainability transitions and intermediaries" section briefly presents the context of sustainability 
transitions and previous literature on innovation intermediaries informing the analysis, followed by a description of the research approach and method in the "Research approach and method" section. The "Findings" section presents the findings of the scholarly case study review. The "Discussion and conclusions" section discusses the results from the perspective of transition theories and intermediation and concludes the paper.

\section{Sustainability transitions and intermediaries}

Multi-level perspective and strategic niche management

The literature on sustainability transitions addresses the problem and dynamics of how to transform existing socio-technical systems to more sustainable configurations. The socio-technical approach implies radical changes not only in technology but also in the surrounding actor-networks, policies and institutions and people's habits, practices and culture (e.g. Markard et al. 2012). While the sustainability transitions approach entails a range of theories, the multi-level perspective (MLP) and strategic niche management (SNM) have been some of the most frequently applied. In the MLP, transition is depicted through interaction between changes in three levels: the landscape, socio-technical regime and niche (e.g. Rip and Kemp 1998; Geels 2002, 2011). The sociotechnical regime refers to the fairly persistent deep structure formed of dominant technologies, infrastructures, formal and cognitive rules including public institutions and policies and the prevailing networks of actors with their practices, beliefs and habits. As opposed to, for example, car-based mobility regimes, Rochracher (2001, p.143) has described building regimes as "rather loosely coupled systems depending on the interaction of various professions (architects, planners, building services, etc.)", and building codes, which regulate the technical standards of buildings, providing "a rather wide framework defining minimum standards - especially with respect to criteria of sustainability (energy use, waste, durability, materials used, etc.)".

While incremental innovation is regarded to occur within the context of the existing socio-technical regime, disruptive innovation activities occur in niches that are associated with initially unstable sociotechnical configurations (Kemp et al. 2001; Hoogma et al. 2002). According to SNM, niches provide spaces of protection for radical innovations (Smith and Raven 2012). For example in the building sector, concepts such as passive houses can be regarded as radical innovations that develop in niches and have not diffused yet to mainstream building regimes. Processes of articulating expectations, creation of new networks and sharing learning have been identified as key for successful niche development (Hoogma et al. 2002; Schot and Geels 2008). These processes provide nurturing for the new innovations, making them more likely to succeed against the preferences in the dominating regime (Smith and Raven 2012).

The landscape level is the hardest to influence, existing largely beyond regime and niche influence (e.g. Geels and Schot 2007) and includes the broader context in which a socio-technical system, such as the building sector, is situated in. It is formed of macroeconomic, macro-political and cultural forces, patterns and development trends creating pressure for changing socio-technical regimes and opening for new innovation niches.

Innovation intermediaries in low energy buildings

In innovation studies, intermediaries are perceived as crucial actors particularly for boundary-crossing innovation by facilitating, configuring and brokering innovation processes (Howells 2006; Stewart and Hyysalo 2008; Klerkx and Leeuwis 2009; Boon et al. 2011). Much of the previous literature on innovation intermediaries focuses on arbitration between the developers of technological or product innovations and their users (e.g. Howells 2006; Stewart and Hyysalo 2008; Hakkarainen and Hyysalo 2016), including Grandclement et al.'s (2015) study on negotiating comfort in low energy housing. Individual studies of a range of actors that could be considered as intermediaries have been published, including consultants (Bessant and Rush 1995) and university technology transfer agencies (Macho-Stadler et al. 2007; Kivimaa et al. 2017). In addition, innovation centres, science parks and innovation financing agencies have been listed as potential intermediaries in innovation processes (e.g. Howells 2006; Polzin et al. 2016). Alternative types of innovation intermediaries, such as Internet market places or energy service companies, have been less explored in the context of intermediating innovation processes. To get a sectoral perspective on innovation 
intermediaries, we focus on reviewing empirical case studies of building energy-related innovations.

A variety of actors operate in the building sector that could act as potential low energy innovation intermediaries. In previous literature, architects (Fischer and Guy 2009; Davies and Osmani 2011), building managers (Grandclement et al. 2015) and regulators (Holm et al. 2011) have been identified to play potential intermediary roles, while their influence in low energy transition is by no means certain. For example, in the UK, Davies and Osmani (2011, p. 1692) have found that there are no legislative drivers to motivate architects to "positively engage in low carbon housing refurbishment design" and at present, architecture companies do not generally take this on as a dominant activity. In addition, organisations such as foundations (Kivimaa 2014) and innovation platforms (Mlecnik 2013a) have been identified to intermediate successfully in advancing low energy housing innovation. Parag and Janda (2014) have examined religious congregations, building professionals, and commercial building communities from the perspective of intermediation (but as middle actors) in low energy innovation, while Arora et al. (2014) mention, for example, the Green Building Council as an intermediary between the demand and the supply of green construction products, in the USA. Maneschi (2013), meanwhile, has examined the intermediary role of a Danish retail bank which provides energy loans. Yet, the importance of innovation intermediaries in the building sector low energy innovation remains rather implicit.

Following several previous studies on intermediaries (e.g. van Lente et al. 2003; Klerkx and Leeuwis 2009; Kivimaa 2014) and contrary to Parag and Janda (2014) and Janda et al. (2016), we perceive intermediaries as actors that may also have agency and capacity to facilitate, configure and broker (cf. Stewart and Hyysalo 2008; Hakkarainen and Hyysalo 2016) systemic change towards low energy buildings. The need for agency relates to the mission through collective action to promote sustainable systemic change. In this context, intermediaries are seen to mediate between production and consumption; to align and consolidate different priorities from politicians, funders, regulators, social interests and other stakeholders; and to mediate the application of these priorities (Hodson and Marvin 2010). In doing so, intermediaries take differing roles with respect to reconfiguring socio-technical regimes (Hodson and Marvin 2010) ranging from project level intermediation to intermediating niche technologies and services locally and globally (e.g. Seyfang et al. 2014; Martiskainen and Kivimaa 2016). Some intermediaries with strong agency ${ }^{1}$ may orient themselves in taking combined championing roles (Martiskainen and Kivimaa 2016), while others act more modestly as mere process or project facilitators (Kivimaa et al. 2016).

This article adds to the literature on innovation intermediaries by focusing on intermediaries in low energy housing innovation processes and, rather than examining particular pre-selected intermediary agents (approach in e.g. Davies and Osmani 2011; Kivimaa 2014; Grandclement et al. 2015), it tries to examine what kind of intermediaries emerge in previously described case studies of low energy building innovations and what roles they take in these processes.

\section{Research approach and method}

Our research approach taken is a systematic review (Petticrew and Roberts 2006) of case studies in a qualitative manner. Following Gerring (2004), a case here is understood to mean an empirical study describing a process of low energy building innovation/process, involving measures such as residential housing refurbishments and zero carbon new build homes (built on site and pre-fabricated) as well as novel business models or programmes for low energy buildings.

The search was limited to a 10 -year range during 2005-2015 and to peer-reviewed academic journal articles listed in Scopus and Web of Science that are major scientific research repositories containing abstracts from thousands of academic journals. Our focus was on peerreviewed academic articles for the following reasons: (1) a systematic review of low energy residential building case studies as reported in academic literature has not been carried out previously; (2) case studies reported in peer-reviewed literature have gone through an academic "quality check" (unlike case studies reported in grey literature, for instance); and (3) peer-reviewed articles found through Scopus and Web of Science based on strict search criteria enable replicability and transparency. The contents of the abstracts of a total of 3120 hits (Table 1) were analysed using the following inclusion

\footnotetext{
${ }^{1}$ Change agents have been described as actors who can champion innovations (Caniels and Romijn 2008) and help build new sociotechnological systems (Kemp et al. 1998).
} 
Table 1 Keyword combinations used in the systematic review

\begin{tabular}{|c|c|c|c|c|c|}
\hline Search & Keyword 1 & [AND] Keyword 2 & [AND] Keyword 3 & Scopus hits & Web of Science hits \\
\hline 1. & $\begin{array}{l}\text { "energy efficiency" [OR] } \\
\text { "energy efficient" [OR] } \\
\text { "low energy" [OR] } \\
\text { "zero carbon" [OR] } \\
\text { "low carbon" [OR] } \\
\text { "passive house" [OR] } \\
\text { "passivhaus" [OR] } \\
\text { "whole house retrofit" [OR] } \\
\text { "energy saving" }\end{array}$ & $\begin{array}{l}\text { "building*" [OR] } \\
\text { "housing" [OR] } \\
\text { "new build" [OR] } \\
\text { "refurbishment" [OR] } \\
\text { "renovation" [OR] } \\
\text { "retrofit*" [OR] } \\
\text { "whole-house retrofit*" [OR] } \\
\text { "deep retrofit"” }\end{array}$ & "innovation*" & $\begin{array}{l}93 \text { hits of which } 18 \text { articles } \\
\text { were relevant for potential } \\
\text { case studies }\end{array}$ & $\begin{array}{l}418 \text { hits of which } 10 \text { articles } \\
\text { were relevant for potential } \\
\text { case studies }\end{array}$ \\
\hline 2. & $\begin{array}{l}\text { "energy efficiency" [OR] } \\
\text { "energy efficient" [OR] } \\
\text { "low energy" [OR] } \\
\text { "zero carbon" [OR] } \\
\text { "low carbon" [OR] } \\
\text { "passive house" [OR] } \\
\text { "passivhaus" [OR] } \\
\text { "whole house retrofit" [OR] } \\
\text { "energy saving" }\end{array}$ & $\begin{array}{l}\text { "building*" [OR] } \\
\text { "housing" [OR] } \\
\text { "new build" [OR] } \\
\text { "refurbishment" [OR] } \\
\text { "renovation" [OR] } \\
\text { "retrofit*" [OR] } \\
\text { "whole-house retrofit"” [OR] } \\
\text { "deep retrofit"” }\end{array}$ & $\begin{array}{l}\text { "technology*" [OR] } \\
\text { "technical change*" [OR] } \\
\text { "niche market*" [OR] } \\
\text { "socio-technical system } \\
\text { change*" [OR] } \\
\text { "actor network system*" [OR] } \\
\text { "building process*" }\end{array}$ & $\begin{array}{l}1333 \text { hits of which } 35 \text { articles } \\
\text { were relevant for potential } \\
\text { case studies }\end{array}$ & $\begin{array}{l}1276 \text { hits of which } 19 \text { articles } \\
\text { were relevant for potential } \\
\text { case studies }\end{array}$ \\
\hline
\end{tabular}

and exclusion criteria: (1) articles outside the discipline of social sciences and humanities were excluded; (2) to have a connection to innovation studies, the article had to contain the word innovation in combination with other key search terms somewhere in the article title, abstract or keywords (later extended to other technology-oriented words as the initial pool of case studies was small, Table 1); (3) to have a common geographical/policy frame of reference, articles outside the EU were excluded from the analysis; and (4) to be included in the review, the article had to contain an empirical case study describing a process of low energy building innovation and its drivers. The case study review, thus, only included so-called uncontrolled real life case studies. A caveat of such case study review is that "[u]ncontrolled studies are more susceptible to bias than studies with control groups, so their results should be treated with caution" (Petticrew and Roberts 2006. p. 65-66).

In the first phase, innovation was used as a search word in all the 57 search term combinations due to our explicit focus on innovation case studies and innovation being a widely diffused word. Each abstract appearing in Scopus was read through to see whether the content related to what the review was searching for. As the initial review only resulted in 18 peer-reviewed journal articles, the review was extended to hand searching the bibliographies of the initially identified sources (cf. Petticrew and Roberts 2006). Hand searching the bibliographies and analysing the contents of those articles that had the theme "buildings" or "homes" in the title and matching the above inclusion/exclusion criteria resulted in two further relevant articles and two cases. The first search phase, thus, resulted in only 20 peer-reviewed journal articles that were subjected to systematic content analysis. Seven articles were subsequently excluded as the more detailed analysis revealed the non-existence of actual case studies (cf. Gerring 2004). In the second phase, the search was extended to Web of Science, which produced 418 hits and 10 additional articles. In the third phase, an extension was made to search terms "technology", "technical change", "niche market", "socio-technical system change", "actor network system" and "building process". This resulted in further 1333 hits in Scopus and 1276 hits in Web of Science. Several hits produced the same articles. From this, we identified 53 potential new articles in Scopus and 31 in Web of Science that we content analysed vis-à-vis our inclusion and exclusion criteria. The purpose of the second and third phases was to test and supplement our initial emerging categories of drivers and intermediary processes. Overall, 28 articles were included in the systemic review containing a total of 40 case studies; six cases being described in more than one source article.

Two researchers coded each article separately following a joint Excel categorisation (see Appendix 1) and deliberated in case of differing interpretations.

\section{Findings}

Overview of the innovation cases

Although in practice multiple demonstration projects and pilots around low energy new builds and retrofits 
have been carried out all over Europe, the review finds that very few have been subjected to academic scrutiny and in-depth qualitative analysis from an innovation studies angle (which is why we extended our systematic review beyond innovation studies). This is besides the wealth of research on the technical qualities, economics, architectural design, domestication, attitudes towards and the policy and politics of low energy buildings (e.g. Aste et al. 2016; Bonnington 2015; Godbolt 2015; Haines and Mitchell 2014; Kuusk and Kalamees 2015; Sobek 2010; Rosenow et al. 2016). What is also surprising is that, what can be classified as qualitative case studies of low energy building innovations or projects promoting them, were found to concentrate only in five EU member states: Belgium, Denmark, Finland, Slovenia and the UK. A broader use of search words pertaining to technology revealed case studies also in France, Germany, Sweden, Spain and the Netherlands, while the predominant focus of the case study literature was in Denmark and the UK.

The cases were predominantly focused on new build (covered by 30 cases), while only nine of the 40 cases related to existing building stock (one case containing both; see Appendix 2). The nature of innovation in the cases was varied including architectural innovation resulting in new buildings that combine a range of energy efficiency and renewable energy measures $(n=11)$, innovative processes showcasing and promoting the commercial application of new low energy housing concepts $(n=8)$, large-scale energy efficient housing development or refurbishment involving systemic and architectural innovation $(n=7)$, renovation projects towards high energy efficiency standards (e.g. Code for Sustainable Homes, Passivhaus Standard) $(n=5)$, piloting sites for ecological living $(n=4)$, new low energy house business models $(n=2)$, an adoption of modular innovation by a mainstream building company $(n=1)$, a new low carbon neighbourhood $(n=1)$ and a new low energy housing knowledge network $(n=1)$. This range shows that innovation in low energy buildings often connects to innovation at a larger scale, including localities and districts (in which low energy building are just one important component) or the development of markets through innovation pull or (business model) innovation push.

In all but one case, a variety of different motivations and drivers were evident, and several cases had more than one key driver (see Appendix 2). The key drivers can be broadly divided into the following eight categories (in the order of importance):

- Environmental drivers (e.g. green values, environmental concerns, climate change, passive house standard, reduced building energy use)

- Policy drivers (e.g. local, government and EU policy comprising climate, planning and innovation policies, Local Agenda 21 movement)

- Eco-social life drivers (e.g. eco-social movements, communal living, alternative lifestyles, mobilising active energy citizens and eco-neighbourhoods)

- Financial drivers (e.g. high energy bills and desire to reduce them, reduced construction costs of ecobuilding)

- Knowledge drivers (e.g. a lack of know-how, influence of previous research programmes, knowledge sharing and replicability, energy-performance gap)

- Social sustainability and equality drivers (e.g. provision of new or better social and/or elderly people's housing, socially sustainable neighbourhoods, regional quality of life)

- Design drivers (e.g. aesthetics, desired space, flexibility to context, historical preservation, sustainable design)

- Health and comfort drivers (e.g. living in healthy homes, comfortable indoor conditions)

- Market drivers (e.g. existing or expected market demand, testing market readiness/applicability to mass markets)

Environmental drivers were evident in the majority of the cases $(n=36)$, including cases initiated by individuals with strong green values and motivated by environmental concerns and climate change or aiming to pioneer in low carbon buildings. For example, in a regeneration project of social housing in Cheshire, UK, client demands encouraged builders to integrate sustainability in their developments (Ozorhon 2013). Interestingly, several cases originated back to eco-oriented societal movements and sustainable housing activists of the 1970 s (see, e.g. Lovell 2008; Holm et al. 2011). In addition, the Passivhaus Standard was a guiding factor in 10 cases. The retrofit pilot of 100 houses in Kerkrade, the Netherlands, for instance, was driven by the Passivhaus Standard and an aim to create living without energy bills (Rovers 2014). 
In 25 out of 40 cases, policy was one of the drivers in the form of influence from international, national and local policy. The articles mentioned the Kyoto Protocol, EU level decisions, national policy agendas and Local Agenda 21 as policies driving innovation. Several of the UK cases specifically mentioned the Code for Sustainable Homes and the Technology Strategy Board's initiatives, such as the Retrofit for the Future programme. The latter was specifically launched in 2009 to "encourage the construction industry to take advantage of the transition to a low carbon economy" and "to explore how retrofit capacity could be radically improved" (Chiu et al. 2014: 574). In other countries, driving policies tended to be either broader national targets or local policies. Many cases had also favourable support from public authorities or other policy actors.

In 14-16 out of 40 cases, local authorities played a positive role through intermediation. It should, however, be noted that in six, i.e. two fifths of these cases (reported in Castán Broto 2012), the same local authority was involved. Local authority involvement manifested, for example, through supportive individuals within the local authority; a municipal housing fund acting as the key actor; a municipality having eco- and energy requirements for new buildings within district area planning; and a local council as a land or property owner. For example, in the UK, "the Newark and Sherwood District Council area, where Hockerton and the Vales's Autonomous House are located, there [has been] an enthusiastic energy manager within the local authority who has supported and encouraged the low-energy housing developments through making connections between key people and helping to develop local low-energy policies" (Lovell 2007b: 38). In addition, in two cases, a specific local policy instrument acted as a driver.

In 22 out of 40 cases, national policy was influential, interestingly with only six cases (all based in Ljubljana, Slovenia and within the same local authority) combining local and national policy influence. In the majority of cases, a mix of policies played a role ranging from RD\&D and deployment subsidies through innovative competitions to building codes and planning regulations. Building regulations have been relatively impor$\operatorname{tant}(n=13)$, while a majority of the cases have not been described as being driven by building regulations. Voluntary government codes, Code for Sustainable Homes in the UK and French Bâtiment Basse Consommation (low energy building), were mentioned as drivers in five cases. For example, a new low energy building for older people was built to the French standard "Bâtiment Basse Consommation" that requires primary energy consumption of less than $50 \mathrm{kWh} / \mathrm{m}^{2} /$ year with some variations to account for climatic differences (Grandclement et al. 2015). Policy changes during the innovation processes have also had influence. For example, energy efficiency subsidies run out during a budget year delaying one project by a year, while another project which initially begun without policy influence had to alter its optimal design type due to the introduction of new building requirements (Pässilä et al. 2015).

Twenty-two cases had eco-social life drivers. These included motivations such as the desire to enable alternative lifestyles, create communal living, follow the principles of sustainable development and provide fair housing. While communal living was more typical to rural locations, some recent urban cases show motivations to create eco-neighbourhoods and active energy citizens (see, e.g. Friesen et al. 2012 and Williams 2012 for the latter).

In 18 out of 40 cases, one of the initiating factors was financial, largely driven by high energy bills and the desire to reduce energy costs but also in two incidences, the reduced costs of sustainable construction. In nine cases, there was a clear motive to provide lower energy bills for social housing tenants to ensure that they were able to pay their rents and hence secure income for the social housing landlord (Castán Broto 2012; Friesen et al. 2012; Sunikka-Blank et al. 2012; Rovers 2014), tying into social sustainability and equality drivers (see below). The regeneration project in Cheshire, UK, was partly influenced by reduced cost of pre-fabricated and timber frame building (Ozorhon 2013).

In 17 cases, knowledge drivers were identified, including cases where existing knowledge played a key role (e.g. one case with a planning team with high capacity and another case with previous research programmes' findings on energy efficient buildings) as well as cases that were driven by a lack of knowledge, e.g. lack of know-how of energy efficient building (Mlecnik 2013a) and lack of innovativeness in the housing industry (Pässilä et al. 2015). The energy performance gap was found a knowledge driver in four cases.

Social sustainability and equality drivers were evident in 13 cases. These included, for example, aims to transform residential areas with social problems (Rovers 2014), improving the quality of life through improved social housing (Ozorhon 2013, Sunikka-Blank et al. 
2012) and increasing community atmosphere and diversity (Friesen et al. 2012).

Design features were evident as a driver in nine cases, including the desire to have not only sustainable but also aesthetically pleasing housing and to create a better space for living (Mlecnik 2010; Pässilä et al. 2015). In addition, design is crucial when energy retrofitting buildings of historical values (Harrestrup and Svendsen 2015).

Health and comfort drivers were evident in only eight cases, health being much less addressed than the indoor comfort of low energy houses: one architectowner aspired to create a healthy home as his child had asthma (Mlecnik 2010), while in another case, one of the key motives was to create not only energyefficient houses but also healthy living environments (Jensen and Gram-Hanssen 2008).

Market drivers were identified in just six cases out of 40. They represented a range from one case experiencing (niche) market demand for passive houses while in another case, the company aimed to be a frontrunner expecting future market demand (Mlecnik 2010; Pässilä et al. 2015). Some cases were also driven by the motivation to test the market readiness or viability of new low energy house concepts (Cronemberger et al. 2014; Palm and Darby 2014).

On average, a case had four different driver categories present (mean 3.85; median 4.00). While there were eight different types of drivers identified for the cases, only environmental, policy and eco-social drivers influenced more than half of all cases. Financial, knowledge and social sustainability and equality drivers influenced about a third of the cases, while design, health and comfort and market drivers were less evident.

Roles, functions and activities of intermediaries

Intermediary actors were explicitly mentioned in relation to five case studies, while our interpretation of the cases identified possible intermediary actors in 26-28 out of 40 cases. This does not necessarily mean that there were no such actors involved in the other cases, as findings only reflect the style in which the cases were written. Particularly the eco-village developments, however, appear independent with little influence from intermediary actors (Smith 2007; Lovell 2008; Holm et al. 2011). Variation in terms of intermediary involvement exists in the other cases (see Appendix 2).
Intermediary actors represented 23-25 different organisations, $13-15$ operating locally and nine nationally and one globally. Ten types were represented: local authority agents (e.g. local councils, planners, an energy manager, a Local Agenda 21 co-ordinator), municipal housing funds/corporations, private housing funds/corporations, business network organisations (trade bodies), independent groups/foundations, government energy agencies, a government innovation agency, consultants, a regional energy utility and an international competition. Public organisations seem to dominate as 19 cases involve public sector intermediaries, while only nine describe private sector intermediaries (in 12 cases, no intermediary-type actors were described).

We found four different processes through which intermediary actors influenced systemic and architectural innovation processes in low energy buildings:

(1) They facilitated concrete building projects by connecting actors, speeding up planning and permitting processes while also aiming to influence local politicians (e.g. Lovell 2007b; Johnson and Dignard-Bailey 2008). Some intermediaries specifically focused on intermediating tenant interests to the building project (Friesen et al. 2012; Sunikka-Blank et al. 2012).

(2) They aimed to create niche markets for new low energy housing innovations through developing planning policies and building requirements in exemplary districts, searching for new technological and policy designs suited to these districts and bringing together entrepreneurs and construction companies to showcase these innovations (e.g. Holm et al. 2011; Quitzau et al. 2012; Williams 2012).

(3) They implemented new practices in publically owned or social building stock by showcasing developments based on a vision of a pioneer low carbon city, bringing together land, knowledge and financial resources and creating new partnerships to realise these developments and learning from the practices and adoption of new technologies by tenants (Castán Broto 2012; Friesen et al. 2012; Sunikka-Blank et al. 2012; Palm and Darby 2014).

(4) They supported processes to create new business models for low energy housing by organising competitions for new housing designs, connecting actors such as architects, house builders and buyers and managing these processes including 
information dissemination, knowledge building and adjusting goals (Heiskanen and Lovio 2010; Pässilä et al. 2015; Cronemberger et al. 2014).

In nearly half of the 40 cases, local authorities seemed to be key players (albeit not always as intermediaries) in the low energy housing innovation processes, including local authority's energy manager (Lovell 2008), municipal planners (Quitzau et al. 2012) and a public/municipal housing funds and corporations (Castán Broto 2012; Gupta and Dantsiou 2013; Palm and Darby 2014). However, it should be noted that six of the cases, where local authority was identified as an intermediary, came from one research project situated in the same city (Castán Broto 2012). When local authority agents have acted as intermediaries (identified in 14-16 cases), they have engaged in the first three processes above but not business model support. Interestingly, in some contexts, private (intermediary) actors have taken similar roles to those described above. For example, an independent Local Agenda 21 group facilitated a similar market creation process in Herfølge, Denmark, as the local authority had taken in Stenlose Syd, Denmark (Holm et al. 2011). In some cases, private social housing providers initiated and facilitated projects to regenerate existing social housing (Ozorhon 2013) and piloting innovations linked to retrofits (Rovers 2014).

A government-owned energy-efficient company, a foundation and an international competition organisation were found to support the fourth process: business model creation. These kinds of actors seem much rarer as intermediaries but are important, because they can reach a geographically wider scope and are less dependent on (local) values, politics and interests than local authority agents. National-scale intermediaries have also facilitated building projects through innovation-oriented funding schemes (Gluch et al. 2013; Chiu et al. 2014).

In only two cases, business network organisations were described to take intermediary roles (Pan and Cooper 2011; Mlecnik 2013a). In Belgium, a passive house platform articulated opportunities for companies, demonstrated passive house designs, provided opportunities for partnering, aided in finding and applying for resources, brokered negotiations with project partners and organised visits and workshops (Mlecnik 2013a). In contrast, the UK Air Source Heat Pump Association, although mentioned explicitly as an intermediary, had relatively little impact on the solution being selected by the house building company (Pan and Cooper 2011).
A fifth process that emerged from the systematic review is not connected to the innovation process but related to (5) facilitating building use, in which intermediaries can educate and negotiate with residents postconstruction on how to use the building and its technical devises (Palm and Darby 2014; Grandclement et al. 2015).

Agency to directly change the regime- not merely to facilitate individual projects - was visible in a few cases, influencing particularly domains such as policy and politics, as well as awareness within the construction industry and consumer preferences. For example, a local energy manager helped policy development and developed planning guidance (Lovell 2007b, 2008). Municipal planners tried to influence politicians and the development of new urban areas by transferring learning to planning requirements (Holm et al. 2011). In the Danish case of Stenløse, the municipality acted as a frontrunner in implementing new planning practices, being an example for other municipalities and the wider regulatory landscape (Holm et al. 2011). In the German case of Vauban, the municipality actively involved the local community in the process of implementing higher energy standards (Williams 2012).

Intermediary actors have also aimed to facilitate knowledge building of low energy housing within the construction industry nationally (Holm et al. 2011; Gluch et al. 2013; Mlecnik 2013a; Pässilä et al. 2015) and globally (Cronemberger et al. 2014) and among house buyers to be more aware of energy concerns (Heiskanen and Lovio 2010). While government innovation and energy agencies were in some cases intermediating a transition through competitive funding schemes (Heiskanen and Lovio 2010; Sunikka-Blank et al. 2012; Chiu et al. 2014; Gluch et al. 2013; Gupta and Dantsiou 2013), the articles did not describe their possible intermediation towards broader institutional or policy change.

\section{Discussion and conclusions}

Dominance of policy and environmental drivers

This systemic review of 40 scholarly case studies on low energy housing innovations, reported in 28 peerreviewed journal articles during 2005-2015, demonstrates that research from an innovation studies angle on this topic is limited. This is exemplified by our initial 
search, explicitly using the word innovation, only leading to 13 articles. Particularly innovation studies on low energy housing in the context of the existing building stock are rare, covered in mere eight articles. We argue, thus, that future research needs to qualitatively explore the processes, drivers and barriers to innovations, as well as intermediary actors, particularly in low/zero energy whole house retrofits. The project specific angle is important to complement the analyses of innovation drivers and barriers carried out from industry perspectives (cf. Arora et al. 2014) and complement studies examining policy development in this domain (e.g. Rosenow et al. 2016; Kern et al. 2017). Furthermore, there is a need for more empirical studies that explore buildings in the aftermath of the 2010 and 2012 policy changes in Europe, when the Directive 2010/31/EU on the energy performance of buildings and the Directive 2012/27/EU amending and repelling previous directives came into force requiring considerable improvements in building energy efficiency. Grey literature could be a valuable source for future studies. It could be used to extend the systematic review beyond scholarly articles, to potentially identify more recent low energy building developments and to test the findings of our review in the context of a greater number of case studies.

The systematic review shows that environmental concerns and eco-social life values have been key drivers (first and third most common) for low energy housing developments, with several reported cases aiming to create buildings that have reduced environmental impact. This shows the importance of values and motivations of actors in innovation processes, sometimes present in "instutionalised" forms such as the Passivhaus Standard. The dominance of value-based drivers is a concern for the broader transition towards low energy buildings (cf. Nykamp in press) in terms of raising questions as to how advances can be made within on a broader scale among (the large majority of) house buyers/owners not motivated by the above. This also points towards the importance of policy (second most common driver) in facilitating the adoption of systemic and architectural low energy innovations in the building stock.

A local authority or national policy (seldom both simultaneously) were supportive elements in over a half of the case studies on advancing building energy efficiency. National policy has particularly influenced through building regulations but also via RD\&D subsidies. Building regulations (as well as voluntary building codes) have been important, as they have usually been repeatedly tightened, sometimes altering project goals, if changing during the innovation process. This indicates that not only the existence of supportive policies but also their dynamics with building sector innovation are crucial, calling for further research, particularly at the absence of connections argued to exist between the construction industry and the science-based research (cf. Arora et al. 2014). While a mix of policies comprising innovation push, market pull and command and control have all been important, the cases address a rather small number of policies given the increased crowdedness of building energy efficiency policy domain, where over 30 policy instruments influencing building energy efficiency have been reported for example in Finland and the UK (Kern et al. 2017). It could be that as increased numbers of policy instruments influence this domain, intermediaries may be needed to translate and simplify what this "messy" world of policy means for individual low energy building and renovation projects. A question remains whether this should be a task of local council planning departments or some other independently operating actors.

The review also demonstrates the importance of policy support in multiple governance levels in achieving innovation in low energy buildings. Impact from policies was assigned from the local level to the Kyoto Protocol, the individual motivations and pressures ranging between projects. In circa half of the case studies, local councils, their planners or energy managers and their housing units were identified to play a role. These roles ranged from initiating and owning projects (often as intermediaries having broader visioning or piloting objectives) to less active roles as supporting low energy building through innovative planning or environmental policies. Variation in the influence of local authority cannot be automatically explained by the extent of power given to the municipal level, because this was seen in countries such as Denmark and the UK alike, which have different types of power arrangements at national and municipal levels with the UK having a far more centralised system than Denmark.

In addition, financial aspects, including not only increasing energy prices and the opportunity to cut bills but also in a few cases reduced costs of sustainable building, have driven almost half of the cases. Similarly, knowledge drivers played a role in almost half of the cases. 
Social sustainability and equality drivers were detected in 13 cases demonstrating that low energy building projects advancing climate policy aims can be coupled with welfare policy aims. Interestingly, these aims were less obvious in the more "innovation studies"-oriented articles. We argue that large-scale public housing stock improvements provide an opportunity to implement more "transformative innovation policy" (cf. Steward 2012) through piloting systemic low energy innovations and simultaneously provide benefits for those living in rented social housing, including reduced fuel poverty, internal comfort and more pleasant residential districts.

Market, health and comfort and design issues were surprisingly rare as reported drivers in the studied innovation processes. This may indicate that a more holistic picture is still missing when pursuing low energy building innovation, although systemic or architectural innovation for reducing the energy demand of buildings should also pay attention to health, comfort and design issues to reduce the number and scale of problems experienced by residents later on. Improved focus on the synergies between energy efficiency, health, comfort and design could also lead to a greater number of systemic innovations in the sector. This is important in regard to creating low energy buildings that are also healthy and comfortable places to live in, especially when buildings become more airtight and more complicated to use (e.g. Chenari et al. 2016).

Added value from intermediaries?

Potential intermediary actors were identified in 26-28 out of 40 cases, while often their activities were not described in much detail. In circa one third of the cases, a local authority agent took on intermediary roles and (a) facilitated a construction process, (b) aimed to create a market for new technological solutions or (c) implemented new technological designs through the social housing stock. As six of these cases were in fact located in the same local authority (Castán Broto 2012), this is an indicative result to be explored in further research. Also, in circa one third of the cases, other types of intermediaries, such as independent foundations, government innovation or energy agencies or business network platforms were shown to play a role. They not only undertook partly similar functions as local authority intermediaries but also contributed to a process of (d) supporting the creation of new business models. In addition, individual (rather than organisational) intermediaries (e) facilitated building use post-construction. While this process does not contribute to the emergence or adoption of systemic and architectural low energy building innovations, it has important implications on the energy saving outcomes of such innovations, especially in relation to the energy performance gap (see e.g. Grandclement et al. 2015). Previously, it has been argued that significant reductions can be achieved in the energy use of buildings through informed maintenance and use practices (e.g. Janda 2011; Grandclement et al. 2015). Interestingly, energy service companies were not identified as intermediaries in any of the case studies (cf. Nolden and Sorrell 2016).

Table 2 shows the five key intermediary processes identified in the systemic review as well as how roles building on Strategic Niche Management links to these processes in the studied cases. The added value of intermediaries in innovation processes associated with low energy buildings is connected with networking, shown by how they connect actors in facilitating building projects; bring together entrepreneurs, construction companies and other actors to create new niche markets and business models; and manage partnerships in implementing new practices in social housing stock. However, intermediaries may also be in a more powerful position to facilitate planning processes (a question of policy influence) - either by being positioned at the local authority or by having good relations with them. Although planning has not been reported among the most significant barriers to low energy innovation in many previous studies (e.g. Davies and Osmani 2011; Holm et al. 2011; Mlecnik 2013a), Vogel et al. (2016) have recently noted the misalignment of innovation and technology advancements with planning processes as a barrier to implementing energy efficiency. This aspect can be important as "companies with a tradition of participation at the planning and building stages" have been assessed better able to introduce innovations into demonstration projects (Mlecnik 2013b). Companies missing this tradition may benefit from intermediaries with connections to the planning process.

Smaller scale, individual building projects and pilots may not radically benefit from intermediaries (e.g. Martiskainen and Kivimaa 2016). However, in market creation, intermediaries are needed as key actors, not only through networking and search for new solutions but also through putting pressure on the existing building regime to change. The added value of such intermediary actors can be to insert sufficient political pressure 
at the local, national or EU level-akin to what has happened in the case of Sitra in Finland (cf. Kivimaa 2014). This upwards directed pressure can be combined with the search for novel business models and showcasing new building/renovation designs that may be more attractive to the market, in a manner of trying to change the regime from different directions at the same time. This idea connects to Parag and Janda (2014) perception of middle actors, while we argue that pressure to different directions should happen at all levels from projects through innovative niches to the regime (or even landscape) — not just in the middle.

Market creation (Pässilä et al. 2015) and the build-up of new innovation and business ecosystems (Heiskanen and Lovio 2010) seem unlikely without intermediaries acting as "keystone" players (cf. Clarysse et al. 2014). Interestingly, what this review demonstrates is that different types of organisations, or individual actors within those organisations, can take this role-from local authority planning departments to independent groups and foundations. Therefore, what seems to be important is that certain intermediary processes are being carried out, rather than who or what kind of actors carry out those processes. Thus, previous studies in the building sector examining particular types of actors as intermediaries (e.g. Fischer and Guy 2009; Parag and Janda 2014) need to be complemented with process-oriented studies on intermediaries in low energy building innovations and their diffusion. Our systematic review makes a start on this and reveals that there is a need for more intermediary action in processes aimed at new market creation and novel business model creation, while there are already several successful examples of facilitation of individual building projects.

Our findings call for more specific studies focusing on the range of intermediary actors that take part in different phases of the innovation process. Future studies should identify crucial intermediary functions in supporting (1) the emergence of low energy innovations in buildings, (2) their diffusion within/to the building regime and (3) the effectiveness of those innovations in practice. The latter links to studies on user innovation (e.g. Hakkarainen and Hyysalo 2016).

It is also likely that new build and renovationoriented low energy innovations require different kinds of intermediary activities from each other which we were unable to uncover due to a limited number of cases on renovations from an innovation studies angle and particularly those portraying intermediary actors. The regimes of new build and renovation are differentiated (e.g. in terms of project ownership, business ecosystems, regulation) but interconnected through some of the same actors and technologies. Therefore, both shared and different intermediaries exist.

Finally, our study shows that while intermediation in low energy building connects to strategic niche management, a much more nuanced view of processes and roles is needed to get insights into what processes intermediaries contribute to in advancing sustainability transitions and what kind of roles they take in doing so. On the basis of the review, we argue that even more project-oriented intermediaries may have capabilities to influence upstream by nudging more systemic change in the construction regime. With respect to policy, our review shows the importance of public policy and politics in driving low energy innovation in the building sector. On that basis, we argue that the connections between energy efficiency policy, innovation policy and welfare policy as well as local and national policy levels should be improved. Many of the case studies demonstrate overlaps between drivers associated with energy saving, social sustainability and innovation. Thus, policies from the different domains (and levels) could jointly reinforce energy efficiency improvements, if decision makers better acknowledge how systemic and architectural innovation can benefit multiple policy goals.

Acknowledgements The research on which this paper is based has been enabled through the Centre on Innovation and Energy Demand, University of Sussex. This manuscript benefited from comments on an earlier version by Professor Benjamin Sovacool and by four anonymous reviewers. An earlier, shorter version of the paper was presented at and included in the proceedings of the World Building Congress, 31 May-3 June 2016. The paper used secondary scholarly data identified through Scopus and Web of Science and accessible through journal publishers, such as Elsevier and Routledge.

\section{Compliance with ethical standards}

Funding This work was supported by the Research Council UK's EUED Programme under Grant EP/KO11790/1 and the Academy of Finland under Grant 288796.

Conflict of interest The authors declare that they have no conflict of interest. 


\section{Appendix}

Table 2 Processes and roles advanced by intermediaries in the reviewed cases

Intermediary roles expanding from SNM Intermediary processes

Facilitate Create niche Create business Implement practices Facilitating building projects markets models in public housing stock building use

\begin{tabular}{|c|c|c|c|c|c|}
\hline $\begin{array}{l}\text { Creating new networks (SNM: Kemp et al. } \\
\text { 1998; Raven and Geels 2010) }\end{array}$ & $\mathrm{X}$ & $\mathrm{X}$ & $\mathrm{X}$ & $\mathrm{X}$ & \\
\hline $\begin{array}{l}\text { Creating visions (SNM: Kemp et al. 1998; } \\
\text { Raven and Geels 2010) }\end{array}$ & $\mathrm{X}$ & & & $\mathrm{X}$ & \\
\hline $\begin{array}{l}\text { Engaging in learning (SNM: Kemp et al. 1998; } \\
\text { Raven and Geels 2010) }\end{array}$ & $\mathrm{X}$ & $\mathrm{X}$ & $\mathrm{X}$ & $\mathrm{X}$ & $X$ \\
\hline $\begin{array}{l}\text { Influencing existing policy processes } \\
\text { (Kivimaa 2014) }\end{array}$ & $\mathrm{X}$ & & & & \\
\hline Creating new policies (Kivimaa 2014) & & $\mathrm{X}$ & & & \\
\hline $\begin{array}{l}\text { Pooling financial and knowledge resources } \\
\text { (SNM interpretation by Kivimaa 2014) }\end{array}$ & & & $\mathrm{X}$ & $\mathrm{X}$ & \\
\hline Managing process (Kivimaa 2014) & & & $\mathrm{X}$ & & $\mathrm{X}$ \\
\hline
\end{tabular}

Table 3 Pre-set categories for case survey of low energy housing innovations

\begin{tabular}{|c|c|}
\hline $\begin{array}{l}\text { 1. General categories providing background } \\
\text { information }\end{array}$ & $\begin{array}{l}\text { 1.1 Definition of innovation used (if any) } \\
\text { 1.2 Related theory/literature } \\
\text { 1.3 Engagement of author with the innovation process (external investigator, active involvement, } \\
\text { leading actor) }\end{array}$ \\
\hline 2. Categorisation of the innovation case & $\begin{array}{l}\text { 2.1 Type of innovation (e.g. technology, service, practice, organisation), as categories to be ticked } \\
\text { 2.2 System innovation (combination of novel technologies, services, practices) yes/no, describe } \\
\text { 2.3 Architectural innovation (novel combination of existing technologies etc.) yes/no, describe } \\
\text { 2.4 Modular innovation (individual innovation, e.g. component of in a building, insulation would } \\
\text { fall into this category) yes/no, describe } \\
\text { 2.5 Incremental/radical innovation (if detectable from the article) }\end{array}$ \\
\hline 3. Empirical detail on the innovation case & $\begin{array}{l}\text { 3.1 Short description of the innovation case } \\
\text { 3.2 Duration of the innovation process (or start year) } \\
\text { 3.3 Geographical location and scale (in minimum country) } \\
\text { 3.4 Existing/new build } \\
\text { 3.5 Type of building if specified (detached house, semi-detached house, terraced house, apartment } \\
\text { building, other) } \\
\text { 3.6 Business model (if described) } \\
\text { 3.7 Initiating factors for the innovation process } \\
\text { 3.8 Other drivers of the innovation process } \\
\text { 3.9 Barriers to the innovation process } \\
\text { 3.10 Role/influence of public policy/local or national governments } \\
\text { 3.11 Actors involved } \\
\text { 3.12 Scaling up potential }\end{array}$ \\
\hline 4. Intermediation & $\begin{array}{l}\text { 4.1 Explicit recognition of intermediaries by the authors, yes/no } \\
\text { 4.2 Type of intermediaries (explicit/implicit) involved in or facilitating the innovation process } \\
\text { 4.3 Niche/systemic intermediaries (select one or both) } \\
\text { 4.4 Roles/functions played by the intermediaries } \\
\text { 4.5 Actors that the intermediary activities target or impact } \\
\text { 4.6 Processes that the intermediary actors target or impact (e.g. information dissemination, funding, } \\
\text { risk reduction) } \\
\text { 4.7 Observed influence of the intermediaries (if mentioned) } \\
\text { 4.8 Neutrality vs. bias of the intermediary } \\
\text { 4.9 Duration of intermediation in the whole process }\end{array}$ \\
\hline 5. Recommendations provided & $\begin{array}{l}\text { 5.1 Policy recommendations } \\
\text { 5.2 Technical recommendations } \\
\text { 5.3 Other }\end{array}$ \\
\hline
\end{tabular}




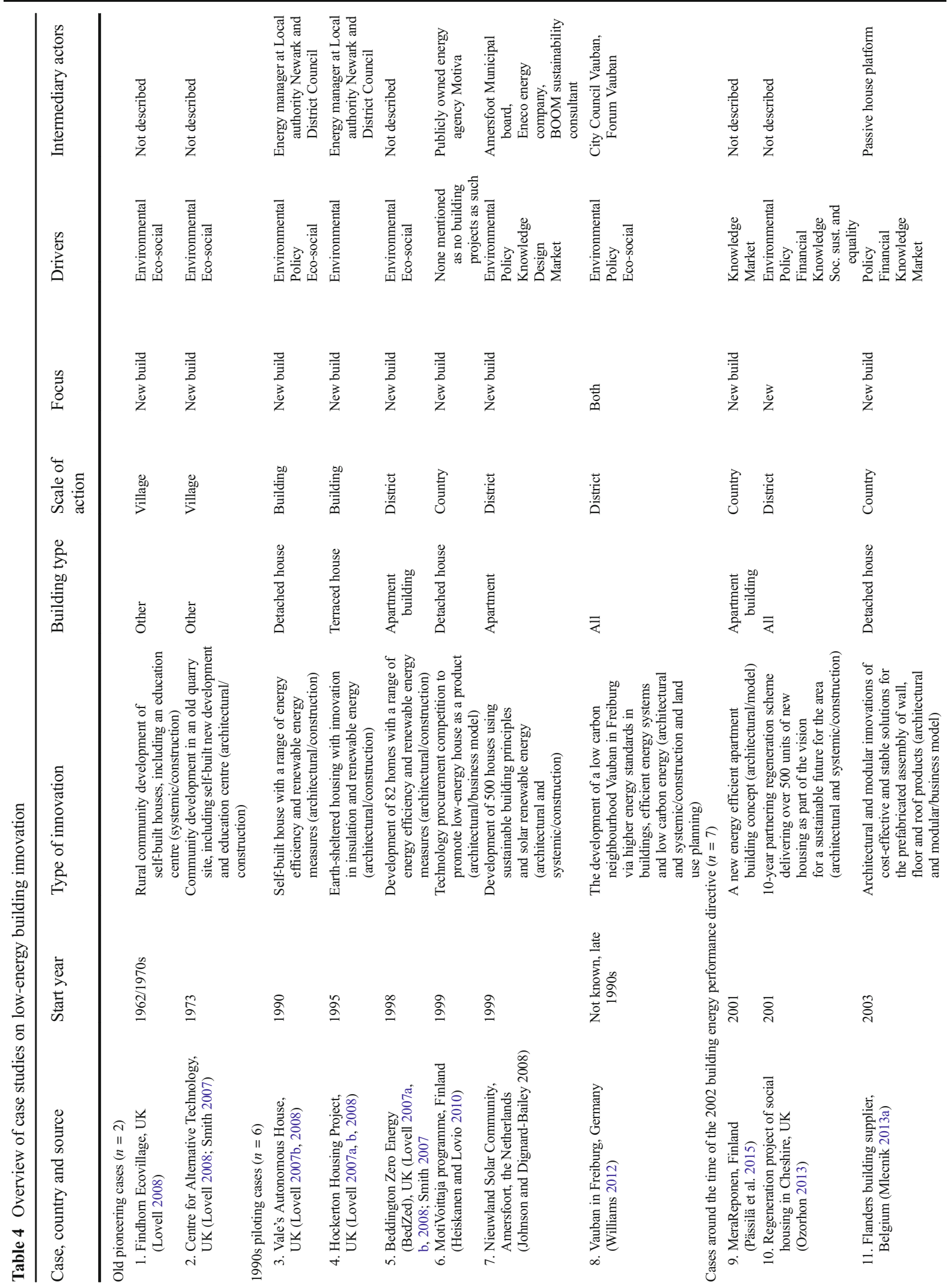




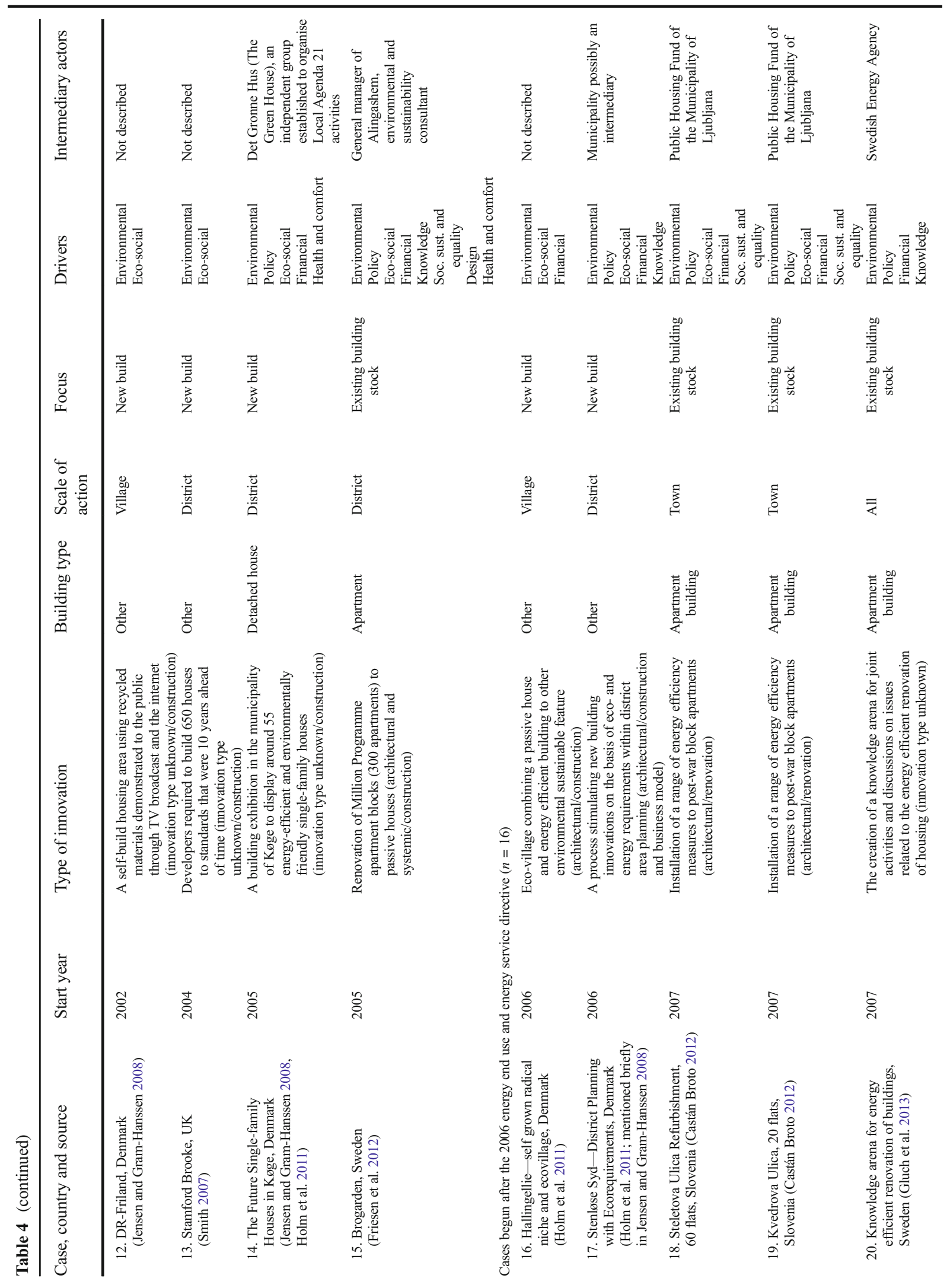




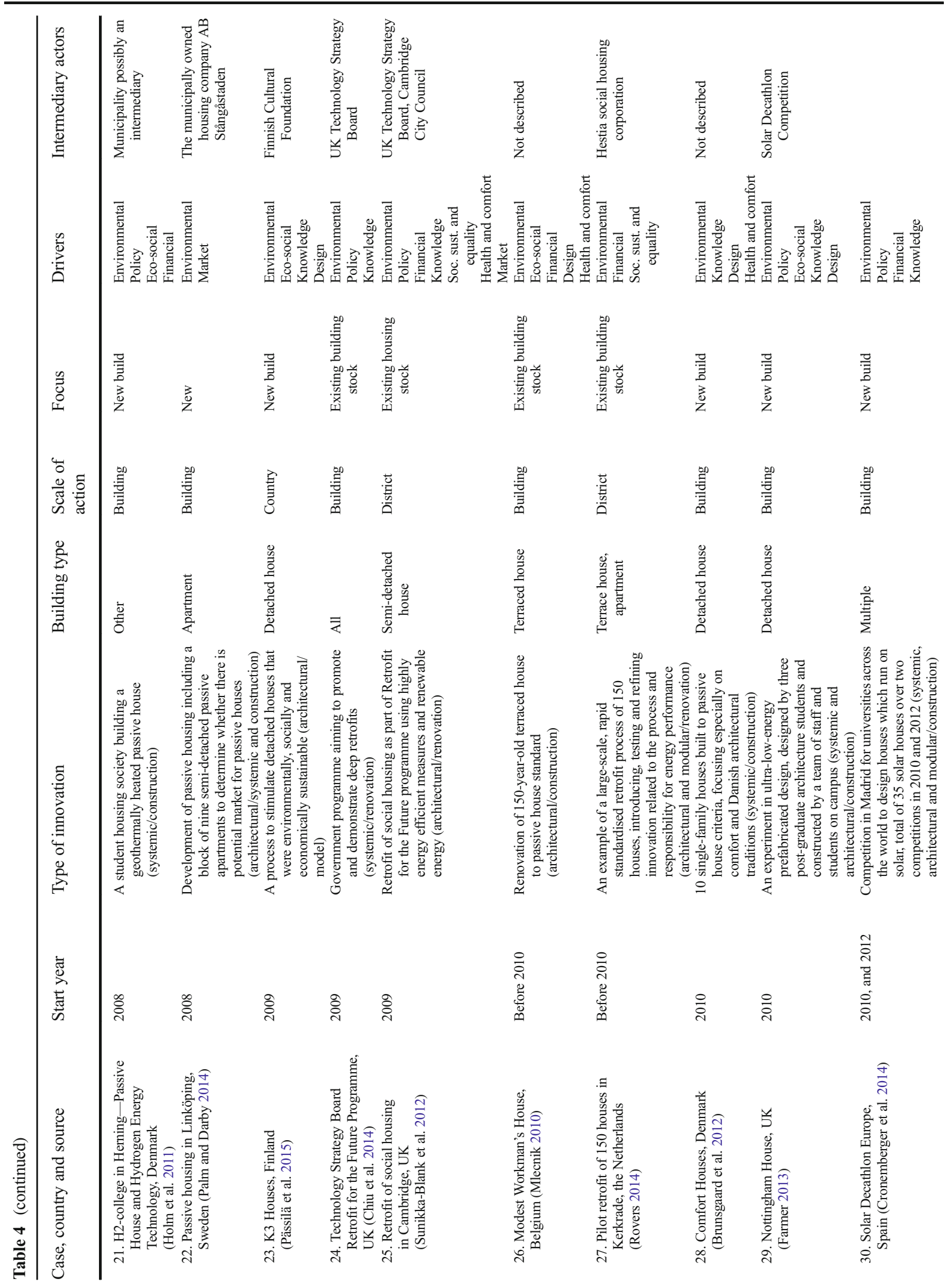




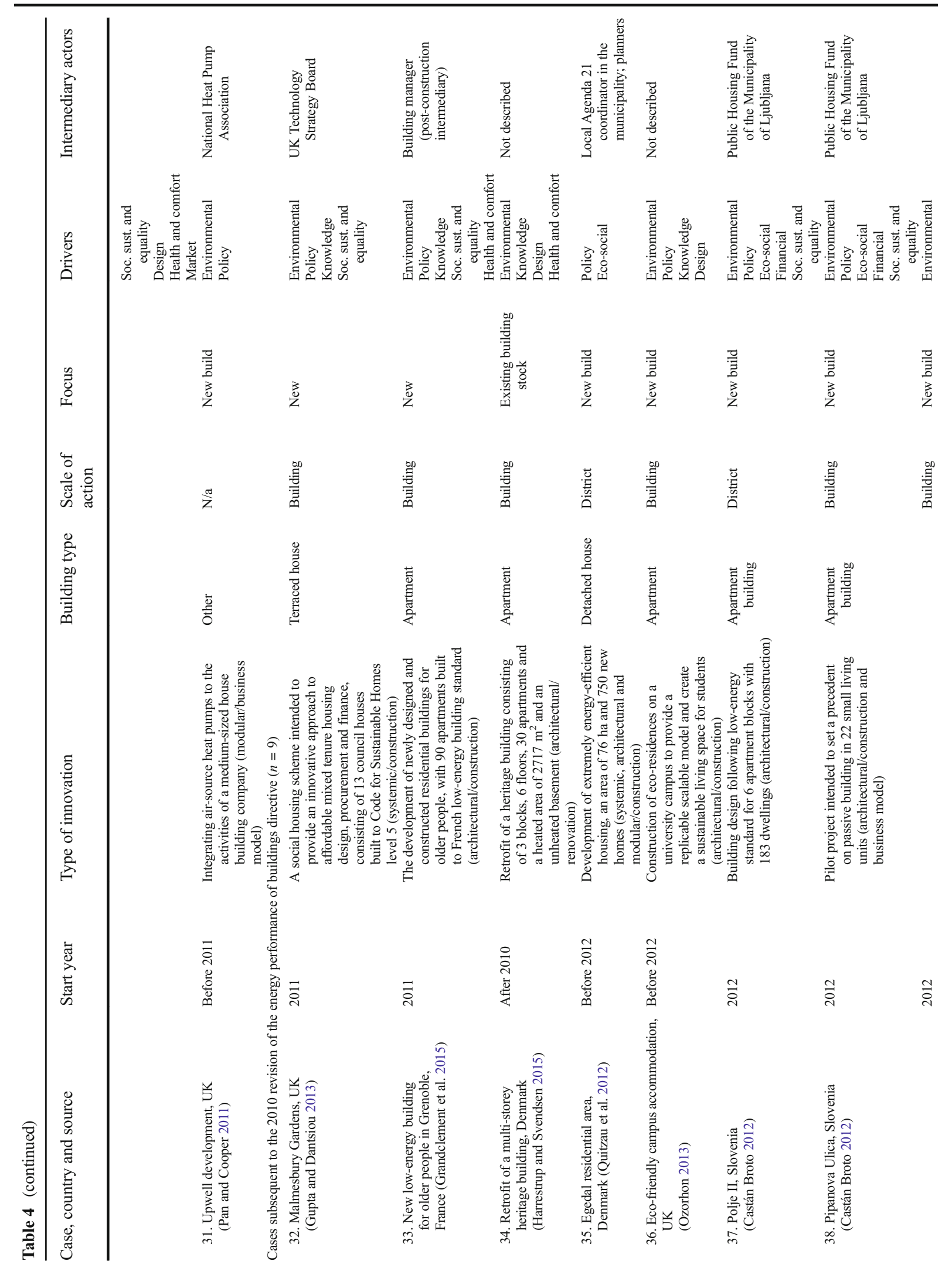


Open Access This article is distributed under the terms of the Creative Commons Attribution 4.0 International License (http:// creativecommons.org/licenses/by/4.0/), which permits unrestricted use, distribution, and reproduction in any medium, provided you give appropriate credit to the original author(s) and the source, provide a link to the Creative Commons license, and indicate if changes were made.

\section{References}

Arora, S., Foley, R., Youtie, J., Shapira, P., \& Wiek, A. (2014). Drivers of technology adoption - the case of nanomaterials in building construction. Technological Forecasting and Social Change, 87, 232-244.

Aste, N., Caputo, P., Buzzetti, M., \& Fattore, M. (2016). Energy efficiency in buildings: what drives the investments? The case of Lombardy region. Sustainable Cities and Society, 20, 27-37.

Barnes, J. (2016). The local embedding of technologies through community-led initiatives: the case of sustainable energy. Doctoral thesis, University of Sussex. http://sro.sussex.ac. uk/61170/. Accessed 24 Nov 2016.

Berry, S., Davidson, K., \& Saman, W. (2013). Defining zero carbon and zero energy homes from a performance-based regulatory perspective. Energy Efficiency, 7(2), 303-322.

Bessant, J., \& Rush, H. (1995). Building bridges for innovation: the role of consultants in technology transfer. Research Policy, 24(1), 97-114.

Bonnington, O. (2015). The indispensability of reflexivity to practice: the case of home energy efficiency. Journal of Critical Realism, 14(5), 461-484.

Boon, W. P. C., Moors, E. H. M., Kuhlmann, S., \& Smits, R. E. H. M. (2011). Demand articulation in emerging technologies: intermediary user organisations as co-producers? Research Policy, 40(2), 242-252.

Brunsgaard, C., Knudstrup, M.-A., \& Heiselberg, P. (2012). Occupant experience of everyday life in some of the first passive houses in Denmark. Housing, Theory and Society, 29(3), 223-254.

Cainarca, G. C., Colombo, M. G., \& Mariotti, S. (1989). An evolutionary pattern of innovation diffusion: the case of flexible automation. Research Policy, 18(2), 59-86.

Caird, S., Roy, R., \& Potter, S. (2012). Domestic heat pumps in the UK: user behaviour, satisfaction and performance. Energy Efficiency, 5, 283-301.

Caniels, M., \& Romijn, H. (2008). Strategic niche management: towards a policy tool for sustainable development. Technology Analysis \& Strategic Management, 20(2), 245266.

Castán Broto, V. (2012). Social housing and low carbon transitions in Ljubljana, Slovenia. Environmental Innovation and Societal Transitions, 2, 82-97. doi:10.1016/j. eist.2012.01.001.

Chenari, B., Dias Carrilho, J., \& Gameiro da Silva, M. (2016). Towards sustainable, energy-efficient and healthy ventilation strategies in buildings: a review. Renewable and Sustainable Energy Reviews, 59, 1426-1447. 
Chiu, L. F., Lowe, R., Raslan, R., Altamirano-Medina, H., \& Wingfield, J. (2014). A socio-technical approach to postoccupancy evaluation: interactive adaptability in domestic retrofit. Building Research \& Information, 42(5), 574-590.

Clarysse, B., Wright, M., Bruneel, J., \& Mahajan, A. (2014). Creating value in ecosystems: crossing the chasm between knowledge and business ecosystems. Research Policy, 43(7), 1164-1176.

Cronemberger, J., Corpas, M. A., Cerón, I., Caamaño-Martín, E., \& Sánchez, S. V. (2014). BIPV technology application: Highlighting advances, tendencies and solutions through Solar Decathlon Europe houses. Energy and Buildings, 83, 44-56.

Davies, P., \& Osmani, M. (2011). Low carbon housing refurbishment challenges and incentives: architects' perspectives. Building and Environment, 46(8), 1691-1698.

Farmer, G. (2013). Re-contextualising design: three ways of practising sustainable architecture. Architectural Research Quarterly, 17(2), 106-119.

Fawcett, T. (2014). Exploring the time dimension of low carbon retrofit: owner-occupied housing. Building Research \& Information, 42(4), 477-488.

Fischer, J., \& Guy, S. (2009). Re-interpreting regulations: architects as intermediaries for low-carbon buildings. Urban Studies, 46(12), 2577-2594. doi:10.1177/0042098009344228.

Freeman, C. (1987). Innovation. In J. Eatwell, M. Milgate, \& P. Newman (Eds.), The new Palgrave: A dictionary of economics (I/IV) (pp. 858-860). London: Macmillan.

Friesen, C., Malbert, B., \& Nolmark, H. (2012). Renovating to passive housing in the Swedish Million Programme. Planning Theory \& Practice, 13(1), 115-130.

Geels, F. (2002). Technological transitions as evolutionary reconfiguration processes: a multi-level perspective and a casestudy. Research Policy, 31, 1257-1274.

Geels, F. (2011). The multi-level perspective on sustainability transitions: responses to seven criticisms. Environmental Innovation and Societal Transitions, 1, 24-40.

Geels, F., \& Schot, J. (2007). Typology of sociotechnical transition pathways. Research Policy, 36, 399-417.

Gerring, J. (2004). What is a case study and what is it good for? American Political Science Review, 98(2), 341-354.

Gluch, P., Johansson, K., \& Räisänen, C. (2013). Knowledge sharing and learning across community boundaries in an arena for energy efficient buildings. Journal of Cleaner Production, 48, 232-240.

Godbolt, A. (2015). The ethos of energy efficiency: framing consumer considerations in Norway. Energy Research \& Social Science, 8, 24-31.

Grandclement, C., Karvonen, A., \& Guy, S. (2015). Negotiating comfort in low energy housing: the politics of intermediation. Energy Policy, 84, 213-222.

Gupta, R., \& Dantsiou, D. (2013). Understanding the gap between "as designed" and "as built" performance of a new low carbon housing development in UK. Smart Innovation, Systems and Technologies, 22, 567-580.

Haines, V., \& Mitchell, V. (2014). A persona-based approach to domestic energy retrofit. Building Research \& Information, $42(4), 462-476$.

Hakkarainen, L., \& Hyysalo, S. (2016). The evolution of intermediary activities: broadening the concept of facilitation. Technology Innovation Management Review, 6(1), 45-58.

Hargreaves, T., Hielscher, S., Seyfang, G., \& Smith, A. (2013). Grassroots innovations in community energy: the role of intermediaries in niche development. Global Environmental Change, 23(5), 868-880.

Harrestrup, M., \& Svendsen, S. (2015). Full-scale test of an old heritage multi-storey building undergoing energy retrofitting with focus on internal insulation and moisture. Building and Environment, 85, 123-133.

Heiskanen, E., \& Lovio, R. (2010). User-producer interaction in housing energy innovations. Journal of Industrial Ecology, 14(1), 91-102.

Henderson, R. M., \& Clark, K. B. (2004). Architectural innovation. In M. L. Tushman \& P. Anderson (Eds.), Managing strategic innovation and change (2nd ed., pp. 92-107). New York: Oxford University Press.

Hodson, M., \& Marvin, S. (2010). Can cities shape socio-technical transitions and how would we know if they were? Research Policy, 39(4), 477-485.

Holm, J., Stauning, I., \& Sondergård, B. (2011). Local climate mitigation and eco-efforts in housing and construction as transition places. Environmental Policy and Governance, 21(3), 183-198.

Hoogma, R., Kemp, R., Schot, J., \& Truffer, B. (2002). Experimenting for sustainable transport: the approach of strategic niche management. London: Spon Press.

Howells, J. (2006). Intermediation and the role of intermediaries in innovation. Research Policy, 35(5), 715-728.

Hyysalo, S., Juntunen, J., \& Freeman, S. (2013). Internet forums and the rise of the inventive energy user. Science \& Technology Studies, 26(1), 25-51.

Janda, K. (2011). Buildings don't use energy: people do. Architectural Science Review, 54, 15-22.

Janda, K., Bright, S., Patrick, J., Wilkinson, S., \& Dixon, T. J. (2016). The evolution of green leases: towards interorganizational environmental governance. Building Research \& Information, 44(5-6), 660-674.

Jensen, J. O., \& Gram-Hanssen, K. (2008). Ecological modernization of sustainable buildings: a Danish perspective. Building Research \& Information, 36(2), 146-158.

Johnson, C., \& Dignard-Bailey, L. (2008). Implementation strategies for solar communities. Open House International, 33(3), 26-37.

Kemp, R., Schot, J., \& Hoogma, R. (1998). Regime shifts to sustainability through processes of niche formation: the approach of strategic niche management. Technology Analysis \& Strategic Management, 10(2), 175-195.

Kemp, R., Rip, A., \& Schot, J. (2001). Constructing transition paths through the management of niches. In R. Garud \& P. Karnoe (Eds.), Path dependence and creation (pp. 269-299). Mahwa (N.J.) and London: Lawrence Erlbaum.

Kern, F., Kivimaa, P., \& Martiskainen, M. (2017). Policy packaging or policy patching? The development of complex energy efficiency policy mixes. Energy Research \& Social Science, $23,11-25$.

Killip, G. (2013). Products, practices and processes: exploring the innovation potential for low-carbon housing refurbishment among small and medium-sized enterprises (SMEs) in the UK construction industry. Energy Policy, 62, 522-530. 
Kivimaa, P. (2014). Government-affiliated intermediary organisations as actors in system-level transitions. Research Policy, 43(8), 1370-1380.

Kivimaa, P., Boon, W., Hyysalo, S. \& Klerkx, L. (2016). From a systematic review to a dynamic typology of intermediaries in transitions. In: SPRU 50th Anniversary Conference, Transforming Innovation, 7-9th September 2016, Brighton.

Kivimaa, P., Boon, W., \& Antikainen, R. (2017). Commercialising university inventions for sustainability - a case study of (non-)intermediating 'cleantech' at Aalto University. Science and Public Policy, in press.

Klerkx, L., \& Leeuwis, C. (2009). Establishment and embedding of innovation brokers at different innovation system levels: insights from the Dutch agricultural sector. Technological Forecasting and Social Change, 76(6), 849-860.

Kuusk, K., \& Kalamees, T. (2015). Retrofit cost-effectiveness: Estonian apartment buildings. Building Research \& Information, 44(8), 920-934.

van Lente, H., Hekkert, M., Smits, R., \& van Waveren, B. (2003). Roles of systemic intermediaries in transition processes. International Journal of Innovation Management, 7(3), 247-279.

Lovell, H. (2007a). Exploring the role of materials in policy change: innovation in low-energy housing in the UK. Environment and Planning A, 39, 2500-2517.

Lovell, H. (2007b). The governance of innovation in sociotechnical systems: The difficulties of strategic niche management in practice. Science and Public Policy, 34(1), 35-44.

Lovell, H. (2008). Discourse and innovation journeys: the case of low energy housing in the UK. Technology Analysis \& Strategic Management, 20(5), 613-632.

Macho-Stadler, I., Perez-Castrillo, D., \& Veugelers, R. (2007). Licensing of university inventions: the role of a technology transfer office. International Journal of Industrial Organization, 25(3), 483-520.

Maneschi, D. (2013). Widening the scope? How intermediary actors can shape energy consumption. European Commission for an Energy Efficient Economy (ECEEE) Summer Study, pp.2367-2377.

Markard, J., Raven, R., \& Truffer, B. (2012). Sustainability transitions: an emerging field of re-search and its prospects. Research Policy, 41, 955-967.

Martiskainen, M. \& Kivimaa, P. (2016) Intermediaries and champions in low energy housing innovation-lessons from case studies in the UK. In: SPRU 50th Anniversary Conference, Transforming Innovation, 7-9th September 2016, Brighton.

Meeus, L., Kaderjak, P., Azevedo, I., Kotek, P., Pato, Z., Szabo, L., \& Glachant, J.-M. (2012). Topic 7: How to Refurbish All Buildings by 2050. Final report of the THINK project funded by EU FP7 programme. European University Institute.

Mlecnik, E. (2010). Adoption of highly energy-efficient renovation concepts. Open House International, 35(2), 39-48.

Mlecnik, E. (2012). Defining nearly zero-energy housing in Belgium and the Netherlands. Energy Efficiency, 5(3), 411431.

Mlecnik, E. (2013a). Opportunities for supplier-led systemic innovation in highly energy-efficient housing. Journal of Cleaner Production, 10, 103-111.

Mlecnik, E. (2013b). Innovation development for highly energyefficient housing (unpublished doctoral thesis). Belgium: Delft University of Technology.
Nolden, C., \& Sorrell, S. (2016). The UK market for energy service contracts in 2014-2015. Energy Efficiency, 9(6), 1405-1420.

Nykamp, H., 2016. A transition to green buildings in Norway. Environmental innovation and societal transitions. (in press).

Ozorhon, B., (2013). Response of construction clients to lowcarbon building regulations. Journal of Construction Engineering \& Management, 139(12). doi:10.1061 /(ASCE)CO.1943-7862.0000768

Palm, J., \& Darby, S. J. (2014). The meanings of practices for energy consumption - a comparison of homes and workplaces. Science and Technology Studies, 27(2), 72-92.

Pan, W., \& Cooper, M. (2011). Decision criteria for selecting air source heat pump technology in UK low carbon housing. Technology Analysis \& Strategic Management, 623(6), 623637.

Parag, Y., \& Janda, K. (2014). More than filler: middle actors and socio-technical change in the energy system from the "middle-out". Energy Research \& Social Science, 3, 102112. doi:10.1016/j.erss.2014.07.011.

Pässilä, P., Pulkka, L., \& Junnila, S. (2015). How to succeed in low-energy housing - path creation analysis of low-energy innovation projects. Sustainability, 7(7), 8801-8822.

Petticrew, M., \& Roberts, H. (2006). Systematic reviews in the social sciences: a practical guide. Malden: Wiley-Blackwell.

Polzin, F., von Flotow, P., \& Klerkx, L. (2016). Addressing barriers to eco-innovation: exploring the finance mobilisation functions of institutional innovation intermediaries. Technological Forecasting and Social Change, 103, 34-46.

Quitzau, M.-B., Hoffmann, B., \& Elle, M. (2012). Local niche planning and its strategic implications for implementation of energy-efficient technology. Technological Forecasting and Social Change, 79(6), 1049-1058.

Raven, R.P.J.M.; Geels, F.W. 2010. Socio-cognitive evolution in niche development: Comparative analysis of biogas development in Denmark and the Netherlands (1973-2004). Technovation, 30, 87-99.

Rip, A., \& Kemp, R. (1998). Technological change. In S. Rayner \& E. L. Malone (Eds.), Human choice and climate change: volume 2: resources and technology (pp. 327-399). Columbus: Battelle Press.

Rochracher, H. (2001). Managing the technological transition to sustainable construction of buildings: a socio-technical perspective. Technology Analysis \& Strategic Management, 13(1), 137-150.

Rosenow, J., Fawsett, T., Eyre, N., \& Oikonomou, V. (2016). Energy efficiency and the policy mix. Building Research \& Information, 44(5-6), 562-574.

Rovers, R. (2014). New energy retrofit concept: "renovation trains" for mass housing. Building Research \& Information, 42(6), 757-767.

Schot, J., \& Geels, F. W. (2008). Strategic niche management and sustainable innovation journeys: theory, findings, research agenda, and policy. Technology Analysis \& Strategic Management, 20, 537-554.

Seyfang, G., Hielscher, S., Hargreaves, T., Martiskainen, M., \& Smith, A. (2014). A grassroots sustainable energy niche? Reflections on community energy in the UK. Environmental Innovation and Societal Transitions, 13, 21-44.

Smith, A. (2007). Translating sustainabilities between green niches and socio-technical regimes. Technology Analysis \& 
Strategic Management, 19(4), 427-450. doi:10.1080 /09537320701403334.

Smith, A., \& Raven, R. (2012). What is protective space? Reconsidering niches in transitions to sustainability. Research Policy, 41, 1025-1036.

Sobek, H. (2010). Radical sources of design engineering. Architectural Design, 80(4), 24-33.

Steward, F. (2012). Transformative innovation policy to meet the challenge of climate change: sociotechnical networks aligned with consumption and end-use as new transition arenas for a low-carbon society or green economy. Technology Analysis \& Strategic Management, 24(4), 331-343.

Stewart, J., \& Hyysalo, S. (2008). Intermediaries, users and social learning in technological innovation. International Journal of Innovation Management, 12(3), 295-325.
Sunikka-Blank, M., Chen, J., Britnell, J., \& Dantsiou, D. (2012). Improving energy efficiency of social housing areas: a case study of a retrofit achieving an "A" energy performance rating in the UK. European Planning Studies, 20(1), 131145.

Tambach, M., Hasselaar, E., \& Itard, L. (2010). Assessment of current Dutch energy transition policy instruments for the existing housing stock. Energy Policy, 38(2), 981-996.

Vogel, J. A., Lundkvist, P., Blomkvist, P., \& Arias, J. (2016). Problem areas related to energy efficiency implementation in Swedish multifamily buildings. Energy Efficiency, 9(1), 109-127.

Williams, J. (2012). Regulative, facilitative and strategic contributions of planning to achieving low carbon development. Planning Theory \& Practice, 13(1), 131-144. 